\title{
A INSUFICIENNCIA DO USO DO CONCEITO DE TRADIÇÃO PELA CRÍTICA HERMENÊUTICA DO DIREITO
}

\author{
THE INSUFFICIENCY OF THE USE OF THE CONCEPT OF TRADITION BY CRITICAL \\ HERMENEUTICS OF LAW
}

LA INSUFICIENCIA DEL USO DEL CONCEPTO DE TRDICIÓN POR LA CRÍTICA HERMENÉTICA DEL DERECHO

\section{Paulo Ferrareze Filho ${ }^{1}$}

O criador da linguagem não foi modesto a ponto de crer que dava às coisas apenas denominações, ele imaginou, isto sim, exprimir com as palavras o supremo saber sobre as coisas; (...) Muito depois - somente agora - os homens começaram a ver que, em sua crença na linguagem, propagaram um erro monstruoso.

Nietzsche ${ }^{2}$

Licença CC BY:

Artigo distribuído sob os termos Creative Commons, permite uso e distribuição irrestrita em qualquer meio desde que o autor credite a fonte original.

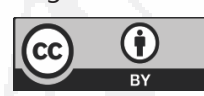

Resumo: $O$ presente diagnóstico busca demonstrar que o uso do conceito de tradição oriundo da hermenêutica filosófica não é capaz de subsidiar a possibilidade de respostas corretas em Direito, tal qual propugna, via Dworkin e Gadamer, a Crítica Hermenêutica do Direito (CHD). Para tanto, o diagnóstico analisa características mitológicas da figura de Hermes Trismegistos, bem como operacionaliza os conceitos nietzschianos de perspectivismo e de morte de deus (história).

Palavra-chave: Fatos. Hermenêutica. Interpretações. Teoria da Decisão. Verdade.

$1 \quad$ Doutor em Direito (UFSC). Mestre em Direito (UNISINOS). Professor de Psicologia Jurídica na Faculdade Avantis. Balneário Camboriú-SC, Brasil. Endereço eletrônico: ferrarezefilho@yahoo.com.br.

2 NIETZSCHE, Friedrich. Humano, demasiado humano. Tradução Paulo César de Souza. São Paulo: Cia das Letras, 2015, p. 79. 
Novos Estudos Jurídicos

\begin{abstract}
The present diagnosis seeks to demonstrate that the use of the concept of tradition derived from philosophical hermeneutics is not able to support the possibility of correct answers in Law, as advocated by Dworkin and Gadamer, Critical Hermeneutics of Law (CHD). For this, the diagnosis analyzes the mythological characteristics of the figure of Hermes Trismegistos, as well as the Nietzschean concepts of perspectivism and death of God (history).
\end{abstract}

Key-words: Facts. Hermeneutics. Interpretations. Right Answer in Law. Decision Theory. Truth.

Resunen: El presente diagnóstico busca demostrar que el uso del concepto de tradición oriundo de la hermenéutica filosófica no es capaz de subsidiar la posibilidad de respuestas correctas en Derecho, tal cual propugna, vía Dworkin y Gadamer, la Crítica Hermenéutica del Derecho (CHD). Para tanto, el diagnóstico analiza características mitológicas de la figura de Hermes Trismegistos, bien como operacionaliza los conceptos nietzschianos de perspectivismo y de muerte de Dios (historia).

Palabras-chave: Hechos. Hermenéutica. Interpretaciones. Teoría de la Decisión. Verdad.

INTRODUÇÃO

A discussão sobre a possibilidade de respostas corretas nas decisões judiciais remonta o velho debate filosófico sobre a (in)existência da verdade. Nietzsche é contumaz ao criticar a vontade de verdade que atua no conhecimento: "a vontade de verdade é a crença, que funda a ciência, de que nada é mais necessário do que o verdadeiro". ${ }^{3}$ Essa discussão, no seio das teorias da decisão judicial, materializase por meio de tentativas doutrinárias de construir critérios capazes de conformar o postulado da segurança jurídica, resultado de um medo humano ancestral que atravessa os tempos e institucionaliza-se por meio do Direito.

Grosso modo, existem três perspectivas de análise oferecidas pela doutrina afeta à decisão judicial. A primeira pode ser sintetizada em torno dos aspectos morais, políticos, pragmáticos e subjetivos envolvidos na decisão4; a segunda

$3 \quad$ NIETZSCHE, Friedrich. A Gaia Ciência. Cia das Letras: São Paulo, 2009. p. 234-236. O autor provoca: "que sabem vocês de antemão sobre o caráter da existência, para poder decidir se a vantagem maior está do lado de quem desconfia ou de quem confia incondicionalmente? E se as duas coisas forem necessárias, muita confiança e desconfiança: de onde poderá a ciência retirar a sua crença incondicional, a convicção de que a verdade é mais importante que qualquer outra coisa? [...] Justamente essa posição não poderia surgir, se a verdade e a inverdade continuamente se mostrassem úteis: como é o caso..."

4 Consultar, entre outros, POSNER, Richard. Cómo deciden los jueces. Barcelona/Madrid: Marcial Pons, 2011; MORAIS DA ROSA, Alexandre. Guia do Processo Penal Conforme a Teoria dos Jogos. 4 ed. Florianópolis: Empório do Direito, 2017; DIVAN, Gabriel. Decisão Judicial nos crimes sexuais: o julgador e o réu interior. Porto Alegre: Livraria do Advogado, 2010; CARVALHO, Luis Gustavo G. C. Estado de Direito e decisão jurídica: as dimensões não-jurídicas do ato de julgar. In: PRADO, Geraldo; MARTINS, Rui Cunha; CARVALHO, Luis G. G. Castanho de (Orgs.). Decisão Judicial: a cultura jurídica brasileira na transição para a democracia. Madri/ Barcelona/Buenos Aires/São Paulo: Marcial Pons, 2012; PRADO, Lidia Reis de Almeida. O juiz e a emoção. 2. ed. Campinas: Ed. Milennium, 2008; PHILLIPE, Jeanine Nicolazi. A lei: uma abordagem a partir da leitura 
trata dos critérios de julgamento das narrativas fáticas em conflito5; e, a última, ocupa-se dos critérios de justificação normativa das decisões.

O estudo que segue busca refletir, a partir da perspectiva das justificações normativistas ${ }^{6}$, as possibilidades de uso do conceito de tradição de H. G. Gadamer a partir da sugestão teórica oferecida pela Crítica Hermenêutica do Direito (CHD) ${ }^{7}$. Trata-se de avaliar os limites do uso dessa ferramenta para construção de uma metodologia capaz de oferecer respostas consideradas corretas nas decisões judiciais ou, como propugna a CHD, respostas adequadas à Constituição

Tendo a filosofia nietzschiana como fio condutor, notadamente a partir dos conceitos de morte da história e de perspectivismo, a reflexão alinha três críticas sobre o uso do conceito de tradição pela CHD: (1) a incompletude da CHD em relação à sua tradição mitológica; (2) a indeterminabilidade dos detalhes da resposta correta via tradição e (3) a insustentabilidade da crença de que a tradição pode autenticar interpretações mais adequadas que outras.

cruzada entre direito e psicanálise. Belo Horizonte: Del Rey, 2001; GULOTTA, Guglielmo. Dinâmica psicossocial da decisão judicial. Revista do Ministério Público do Rio Grande do Sul, Porto Alegre, v. 1, n. $22,1989$.

Consultar, para tanto, especialmente a obra de José Calvo González, Michelle Taruffo e Bernard Jackson, dentre as quais se destacam: CALVO GONZÁLEZ, José. Derecho y Narración: materiales para una teoría crítica narrativista del Derecho. 1. ed. Editorial Ariel: Barcelona, 1996; CALVO GONZÁLEZ, José. A controvérsia fática: contribuição ao estudo da quaestio facti a partir de um enfoque narrativista do Direito. In: TRINDADE, André Karam; GUBERT, Roberta; COPETTI NETO, Alfredo (Orgs.). Direito e Literatura: discurso, imaginário e normatividade. Porto Alegre: Núria Fabris Editora, 2010; CALVO GONZÁLEZ, José. O Direito Curvo. Porto Alegre: Livraria do Advogado, 2013; TARUFFO, Michele. Precedente e Jurisprudência. Revista de Processo, São Paulo, v. 199, 2011; TARUFFO, Michele. La prueba de los hechos. 4. ed. Traducción de Jordi Ferrer Beltrán. Madrid: Editorial Trotta, 2011; JACKSON, Bernard. Law, Fact and Narrative Coherence. Liverpool: Deborah Charles Pub, 1998; JACKSON, Bernard. Narrative Models in Legal Proof. In: Narrative and the Legal Discourse: a reader in Storytelling and the Law. Liverpool: Deborah Charles Pub, 1991.

6 Streck confirma sua adesão a esta terceira perspectiva ao afirmar: "Minha concepção é normativa. Pretendo dizer, doutrinariamente, como os juízes devem decidir". Em STRECK, Lenio. Hermenêutica e Jurisdição: diálogos com Lenio Streck. Porto Alegre: Livraria do Advogado, 2017. p. 13.

7 Conforme Streck, "para alcançar a resposta correta - denominada na CHD de resposta adequada à Constituição - utilizou-se o caminho promissor desenhado a partir da imbricação da hermenêutica filosófica gadameriana com a teoria da integridade de Dworkin [...] Para Dworkin, "ao decidir cada novo caso, o juiz deve considerar um complexo empreendimento em cadeia, do qual inúmeras decisões, estruturas e convenções fizeram parte da histórica...Assim, é necessário continuar essa história no futuro por meio da decisão que o juiz toma. Ele deve interpretar o que aconteceu antes porque tem a responsabilidade de levar adiante a incumbência que tem em mãos e não partir em alguma nova direção." STRECK, Lenio. Dicionário de Hermenêutica: Quarenta temas fundamentais da Teoria do Direito à Luz da Crítica Hermenêutica do Direito. Belo Horizonte: Casa do Direito, 2017. p. 252-254.

8 "[...] a democracia sempre corre perigo se a aplicação do Direito pelos juízes e Tribunais é feita sem uma adequada teoria da decisão judicial, enfim, de uma criteriologia e, finalmente, sem mirar em uma resposta correta, que a partir da Crítica Hermenêutica do Direito denomino de resposta adequada à Constituição." STRECK, Lenio. Dicionário de Hermenêutica. p. 253-254. 
O método proposto pela CHD fixa tese de que as aporias hermenêuticas nas decisões judiciais podem ser resolvidas a partir de um diálogo autêntico com a tradição9. De acordo com os marcos teóricos adotados por essa corrente, esse diálogo pode ser desdobrado em dois vieses: $1^{\circ}$ ) atender a tradição dos fenômenos e institutos que se entrecruzam e, de mais a mais, conflitam-se em um julgamento (Gadamer) ${ }^{10}$; e $2^{\circ}$ ) manter a integridade do Direito observandose e sendo coerente com a tradição de jurisprudências similares em um ou mais aspectos $^{11}$, seguindo a conhecida fórmula do romance em cadeia de Dworkin ${ }^{12}$.

Considerando que, de acordo com a CHD, a interpretação, para ser autêntica, deve ser duplamente contaminada pela tradição (fenomênica e jurisprudencial), dialogar com os detalhes que caracterizam a figura histórica de Hermes é atender à sua própria proposta teórica.

Do ponto de vista histórico-mitológico, a CHD corrobora a tradição grega, anotando que a palavra grega hermeneuein remonta a Hermes Trismegistos, "mensageiro divino que transmitia o conteúdo da mensagem dos deuses aos mortais", localizando o drama hermenêutico no fato de que "nunca se soube o que os deuses disseram, mas apenas o que Hermes disse acerca do que os deuses disseram"13.

9 "Para alcançar a resposta correta - denominada pela CHD de resposta adequada à Constituição - utilizou-se o caminho promissor desenhado a partir da imbricação da hermenêutica filosófica gadameriana e da teoria da "law as integrity" de Dworkin [...] apostando, respectivamente, na tradição, coerência e integridade". STRECK, Lenio. Dicionário de Hermenêutica.. p. 254.

10 "Não se exige, portanto, um desenvolvimento da história efeitual como nova disciplina auxiliar das ciências do espírito, mas que se aprenda a conhecer-se melhor a si mesmo e reconheça que os efeitos da história efeitual operam em toda compreensão, esteja ou não consciente disso. Quando se nega a história efeitual na ingenuidade da fé metodológica, a consequência pode ser até uma real deformação do conhecimento." GADAMER, H. G. Verdade e Método. Tradução de Flávio Paulo Meurer, 7ª ed. Petrópolis, RJ: Vozes, p. 450.

11 "Qualquer juiz obrigado a decidir uma demanda descobrirá, se olhar nos livros adequados, registros de muitos casos plausivelmente similares, decididos há décadas ou mesmo séculos por muitos outros juízes, de estilos e filosofias judiciais e políticas diferentes, em períodos nos quais o processo e as convenções judiciais e era diferentes...". DWORKIN, Ronald. Uma questão de princípio. 2. ed. Tradução de Jefferson Luiz Camargo. São Paulo: Martins Fontes, 2005. p. 235.

12 Conforme Dworkin, a interpretação de um juiz pode ser equiparada a um romance que é intermitentemente escrito por todos os juízes de um sistema judicial. Esclarece o autor: "Em tal projeto, um grupo de romancistas escreve um romance em série; cada romancista da cadeia interpreta os capítulos que recebeu para escrever um novo capítulo, que é então acrescentado ao que recebe o romancista seguinte, e assim por diante". DWORKIN, Ronald. O império do Direito. 2. ed. Tradução de Jefferson Luiz Camargo. São Paulo: Martins Fontes, 2007. p. $275-279$.

13 STRECK, Lenio. Hermenêutica jurídica. In: BARRETO, Vicente de Paulo. Dicionário de Filosofia do Direito. Ed. Unisinos/Renovar: São Leopoldo/Rio de Janeiro, 2006. p. 430. 
Ainda que se reconheça que o papel mais típico de Hermes era o de mensageiro dos deuses imortais, Mircea Eliade ${ }^{14}$ esclarece que Hermes, além de deus da comunicação e da escrita, era também um deus com capacidades mágicas. Para além da tarefa de mensageiro-escritor, Hermes também está familiarizado com o misticismo, a magia, a alquimia e as ciências ocultas que dominavam o imaginário popular e filosófico na transição da antiguidade para o medievo.

Serra informa que a proximidade de Hermes com o mundo das trevas se deve ao fato de sua mãe ter se apartado da assembleia dos olímpicos, em um ermo escuro, para poder receber a visita amorosa do soberano celeste, que descia à caverna ctônica para possuí-la. Assim, nota-se que extremos opostos estão combinados na gênese de Hermes: a elevação celeste e a profundeza da terra ${ }^{15}$.

Viajante das três dimensões da existência, de acordo com a cosmogonia antiga, Hermes circulava livremente entre as trevas escuras da noite, as planícies e planaltos terrestres e o cimo celeste do Olimpo. Acabou, por isso, transformandose em um deus psicopompo ${ }^{16}$, com a atribuição de conduzir as almas entre o ctônio, o terrestre e o celestial ${ }^{17}$. É a condição de viajante, ou seja, a de alguém que enfrenta as brutais e peculiares diferenças entre os lugares e as almas dos três planos com uma naturalidade técnico-profissional, que torna Hermes astuto, guardião e inteligente, mas também embusteiro, multiardiloso e ladrão, revestindo-se, portanto, de uma aura tão mágica quanto ambígua ${ }^{18}$.

Para a psicologia ${ }^{19}$, os registros judaico-cristãos de céu e de inferno representam os planos consciente e inconsciente. Brendão ${ }^{20}$ confirma tal ideia

14 ELIADE, Mircea. História das crenças e das ideias religiosa. Rio de Janeiro: Editora Zahar, 2011. v. 2. p. 258261.

15 HOMERO. Hino Homérico a Hermes. Tradução e comentários de Ordep Serra. São Paulo: Odysseus Editora, 2006. p. 34.

16 Do grego чuхотонто́ (psychopompós), a palavra se compõe de psyché, "alma", e pompós, aquele que guia ou conduz.

17 Conforme Junito de Souza Brandão, de acordo com os mitos cosmogênicos, a organização do cosmo é secionada em três níveis diferentes: o celeste, o telúrico e o ctônio. O primeiro representa o local privilegiado dos deuses do Olimpo; o segundo refere-se à superficialidade da terra (Gaia); e o último, ao universo profundo da terra que pouco se conhece. BRENDÃO, Junito de Souza. Mitologia grega. 18. ed. Petrópolis, RJ: Vozes, 2009. v. I. p. 160. HOMERO. Hino Homérico a Hermes. p. 39.

19 Veja-se o capítulo "O problema do quarto componente" em JUNG, Carl G. Interpretação psicológica do Dogma da Trindade. 8. ed. Petrópolis, RJ: Vozes, 2011. p. 71-102; além da lembrança feita por Jacob Pinheiro Goldberg, ao anotar que Freud, na abertura do clássico "A Interpretação dos Sonhos", cita Virgílio: "se não posso mover os céus, moverei o inferno". Tal postura pode representar um pedido de licença de Freud às potestades do Inferno para penetrar no mundo dos sonhos e do inconsciente. Essa dicotomia, diz o autor, "está sempre nas revelações ocultistas de que o que está em cima (consciente) é semelhante ao que está embaixo (inconsciente). Céu e Inferno". GOLDBERG, Jacob Pinheiro. Psicologia e reflexos do inconsciente. São Paulo: Jacob Pinheiro Goldberg Editora, 1978. p. 104.

20 BRENDẪ, Junito de Souza. Mitologia grega. v. I. p. 274. 
ao dizer que "a grande mágica das manifestações noturnas simbolizaria o inconsciente, onde se agitam monstros, espectros e fantasmas". O autor analisa as características de Hermes e também ressalta sua proximidade com as sabedorias ocultas:

O que interessa mais de perto nesse deus [...] são suas relações com o mundo dos homens, um mundo por definição aberto, que está em permanente em construção, isto é, sendo melhorado e superado. Os seus atributos primordiais - astúcia e inventividade, domínio sobre as trevas, interesse pela atividade dos homens, psicopompia serão continuamente reinterpretados e acabarão por fazer de Hermes uma figura cada vez mais complexa, ao mesmo tempo que um deus civilizador, patrono da ciência e imagem exemplar das gnoses oculares ${ }^{21}$.

A premissa mitológica de que Hermes vale-se da inventividade para transmitir mensagens conduz a uma inconveniente fatalidade: a de que interpretar é, em suma, se dedicar ao erro. O eixo central do viés mitológico, que funda a noção hermenêutica, está, assim, muito mais afeito à ideia de traição do que de tradição.

Três aspectos da história de Hermes são relevantes para demonstrar que a concepção hermenêutica propugnada pela CHD pode ser complementada ao se aproximar não só do Hermes-mensageiro, mas também do Hermes-embusteiro. (1) Conta-se que, depois de deixar o ventre, Hermes roubou gado de seu irmão Apolo. Para não deixar rastros das reses no chão, amarrou galhos de árvore em seus rabos para que as pegadas fossem apagadas. (2) Sublinha-se a condição de viajante voador de Hermes. Com sandálias aladas, se elevava à condição dos animais voadores, que, diferente do animal de rebanho, passa sem deixar rastro, marcas ou pegadas, dificultando, assim, a possibilidade de retorno ao passado, à tradição. (3) Hermes, deus das palestras e da escrita, valia-se do artifício da ironia e da retórica. A ironia está na origem do episódio de saudação à tartaruga, que, seduzida pela retórica de Hermes, é morta por ele. É usando o recurso da ironia e da retórica ${ }^{22}$ que Hermes consegue construir, com o casco da tartaruga morta, a lira que usará como moeda de troca para enganar Apolo e roubar-lhe o gado.

21 BRENDÃO, Junito de Souza. Mitologia grega. v. II. p. 196.

22 No Crátilo, Platão associa Hermes ao Lógos, afirmando que "as características de intérprete, de mensageiro, de desenvolto no furto, de enganador com palavras e de hábil comerciante, todas essas atividades relacionam-se com o poder do discurso. 
É a partir desse diálogo com a tradição mitológica de Hermes que se constata não ser possível louvar nenhuma perspectiva teórica que despreze o elemento da ambiguidade, tão próprio ao patrono simbólico da hermenêutica. Incorporandose as demais características de Hermes, acrescenta-se ao drama interpretativo o caráter embusteiro, persuasivo e oculto das mensagens herméticas, além das dificuldades de encontrar mecanismos que possam orientar a reconstrução da gênese das mensagens.

Pode-se dizer que a falta de investigação dos aspectos ocultos implicados na decisão judicial, temática desenvolvida por concepções teóricas que vão além da busca de critérios narrativos e normativos, gera certo estado de esquizofrenia teórica que impede o avanço dos esclarecimentos pertinentes ao dilema da decisão judicial.

\section{CRÍTICA AO USO DO CONCEITO DE TRADIÇÃO COMO CONDIÇÃO DE POSSIBILIDADE DE RESPOSTAS CORRETAS EM DIREITO}

O que se encontra no começo histórico das coisas não é a identidade ainda preservada da origem - é a discórdia entre as coisas, é o disparate.

Michel Foucault23

A CHD, apoiada no postulado da hermenêutica filosófica de que toda a interpretação é condicionada por pré-compreensões ${ }^{24}$, arvora-se na hipótese de que investigar, problematizar e dialogar com a tradição é a postura afirmativa do intérprete capaz de realizar interpretações autênticas. É a partir desse exercício necessariamente psíquico e mental, mediado pelo contato com textos pretéritos, que o julgador processa e registra a possibilidade de fornecer verdades jurídicas, respostas corretas, autênticas ou, como quer a CHD, adequadas à Constituição.

23 FOUCAULT, Michel. Microfísica do poder. 24. ed. Tradução Roberto Machado. Rio de Janeiro: Edições Graal, 1979. p. 18.

24 GADAMER, Hans-Georg. Verdade e Método I. 7. ed. Tradução de Flávio Paulo Meurer. Petrópolis, RJ: Editora Vozes, 2005. Ainda, GADAMER, Hans-Georg. Hermenêutica em retrospectiva: a virada hermenêutica. Tradução de Marco Antônio Casanova. Petrópolis, RJ: Vozes, 2007. v. II. E, por fim, GADAMER, Hans-Georg. Hermenêutica em retrospectiva: a posição da filosofia na sociedade. Tradução de Marco Antônio Casanova. Petrópolis, RJ: Vozes, 2007. v. IV. 
E se a CHD incorpora o conceito de tradição da hermenêutica filosófica, refletir sobre as possibilidades de uso desse conceito é refletir a própria posição e articulação do conceito feita pela hermenêutica filosófica de Gadamer.

Para essa matriz, toda tentativa de interpretação busca (des)velar sentidos a partir da circularidade hermenêutica daquele que interpreta. O intérprete, segundo Gadamer, deve suspender seus próprios (pré)juízos - como a separar o joio do trigo -, fazendo com que os (pré)juízos autênticos se diferenciem dos inautênticos. Ao suspender (leia-se, esquecer) os (pré)juízos inautênticos, e, por isso, legitimar os (pré)juízos autênticos mediante um pretenso "diálogo com a tradição", o intérprete alcançará, de acordo com a CHD, uma interpretação autêntica/legítima/correta/adequada.

Para traçar, didaticamente, os contornos da crítica do uso do conceito de tradição pela CHD, imagine-se a seguinte situação. No elevador de um edifício de apartamentos residenciais há o seguinte recado do síndico: "Caro condômino: em função dos problemas na estrutura hidráulica do edifício, escreva no painel ao lado qual o melhor dia e horário para que você possa receber a visita do encanador". Agora, considere-se que um dos moradores não designe um horário preciso e escreva no painel o seguinte: "Nome: João da Silva - Apartamento: 201 - Melhor horário: final da tarde".

Diante da indeterminação do texto de João da Silva, o uso do conceito de tradição pela hermenêutica filosófica/CHD seria útil para compreender que João não pretende receber a visita do encanador às 15 ou às 21 horas. Por outro lado, essa "resposta correta", que ecoa via "tradição", não poderá ser útil para desvendar se João pretende receber a visita do encanador às 17, às 18 ou às 19 horas, afinal, todos esses horários podem ser considerados como "fim da tarde".

Assim, ao mesmo tempo em que é possível concordar com a proposta feita pela hermenêutica filosófica e pela CHD de que a tradição pode oferecer - não uma resposta correta - mais uma "direção de sentido", por outro lado, é necessário constatar a insuficiência metodológica para que se possa conhecer, dentro da direção sugerida pela tradição, a(s) resposta(s) correta(s) de um determinado caso. Dito de outro modo: ao mesmo tempo em que a hermenêutica e o pretenso diálogo com a tradição isolam camadas de juízos prévios que são inautênticos por 
obviedade - o que, admita-se, é um mérito -, por outro lado, não permitem que nesse material de juízos prévios se possa encontrar uma interpretação "correta". Submetido a toda sorte de contingências, subjetividades e variabilidades, esse "corpo" de juízos prévios, contornado pela força da tradição, não é capaz de indicar o lugar exato onde se poderá encontrar uma resposta correta levada realmente a sério.

Concorda-se com a afirmação de Gadamer e, por conseguinte, da CHD, de que uma interpretação é autêntica quando dialoga com a tradição e permite que a "coisa em si" fale. Não admitir esse postulado significaria dizer que seria razoável que o encanador chegasse à casa de João da Silva às $21 \mathrm{~h}$. O fato é que esse postulado não ajuda a saber se o encanador deve ir às $17 \mathrm{~h}$, às $18 \mathrm{~h}$ ou às $19 \mathrm{~h}$, donde se detecta a fissura da proposta de resposta correta pela CHD. A s s i m, ao mesmo tempo que se concorda que um pretenso diálogo com a tradição pode orientar uma interpretação, percebe-se que ele não é capaz, por si só, de precisar respostas. Se, nesse sentido, o presente estudo comunga de parte da metodologia da CHD, também rechaça a indiferenciação que ela faz sobre os easy e os hard cases.

Casos como o do exibicionista ejaculador do ônibus de São Paulo ${ }^{25}$, o da censura do livro Orixás, Caboclos e Guias, deuses ou demônios? do pastor Edir Macedo ${ }^{26}$, ou mesmo, o do transexual que perdeu direito à pensão do pai militar ${ }^{27}$ são alguns exemplos de como a CHD não consegue justificar, mesmo dialogando com a tradição, porque determinadas respostas jurídicas são menos autênticas do que outras. Ao negar as zonas de penumbra ou de indeterminação, a CHD ultrapassa teoricamente a barreira do humanamente possível.

Assim, propõe-se a distinção entre uma função primária e outra secundária da interpretação: a primeira, que secciona o material oferecido pela tradição; e a

25 Ver STRECK, Lenio. Sobre como o direito nos funda e a moral nos afunda. Consultor jurídico, São Paulo, 7 set 2017. Disponível em: <http://www.conjur.com.br/2017-set-07/senso-incomum-ejaculador-direito-funda-moralafunda $\geq$. Acesso em: 20 nov 2017.

26 Trata-se do Agravo de Instrumento $n^{\circ}$ 2005.01.00.069605-8, em que o Tribunal Regional Federal da $1^{\circ}$ Região (TRF-1) foi instado a se manifestar sobre pedido do Ministério Público Federal para suspender a circulação da obra Orixás, Caboclos e Guias, deuses ou demônios? (2004), de autoria do bispo da Igreja Universal do Reino de Deus, Edir Macedo, em razão do conteúdo ofensivo da obra às religiões afro-brasileiras. Consultar notícia em: http://www.conjur.com.br/2005-dez-07/edir macedo nao vender livro decide trf-1.

27 Consultar notícia em: http://www.gazetadopovo.com.br/justica/filho-transexual-de-militar-perde-direito-a-pensao94II5n7rcchgw6aj480yd0qmc. 
segunda, que justifica porque se elege determinada resposta em detrimento de outras, afirmando uma e rechaçando detalhadamente as demais.

Quando, apropriando-se de Gadamer, para quem "é à gênese da consciência histórica que a hermenêutica deve sua função central no âmbito das ciências do espírito"28, Streck arvora sua proposta de resposta adequada à CF, desconsidera o que aqui se denomina de função secundária da interpretação, ou seja, os exercícios interpretativos aptos a determinar, a partir do material já "desvelado" pela tradição, detalhes capazes de dizer qual interpretação é a (mais) correta, a mais adequada à Constituição, enfim, a melhor em cada caso. Daí que as teorias da argumentação, antes de discursos apofânticos de segundo nível vinculados à estrutura dada pela hermenêutica, são os meios pelos quais se poderá justificar a opção entre aquelas oferecidas pela estrutura hermenêutica enraizada na faticidade. É o "discurso de segundo nível", retornando do discurso hermenêutico, aquele capaz de justificar a resposta - não correta - mas eleita dentre as entregues pela tradição ${ }^{29}$.

Afinal, como é possível encontrar, dentro do conjunto de respostas óbvias que a tradição oferece (17h, $18 \mathrm{~h}$ ou 19h?), a resposta (correta) dentre a miríade de respostas autenticadas pela tradição? Quais são as condições pelas quais coincidem a intenção do morador João com a compreensão e a interpretação do encanador? - quiçá primeiro do síndico e só depois do encanador... Ou, ainda: por que o ejaculador de São Paulo não pode ser enquadrado no artigo 215 do $\mathrm{CP}$ ? Ou por que a liberdade de expressão prevalece sobre a liberdade religiosa no caso do livro de Edir Macedo? Ou, por fim, por que uma mulher que deseja ter pênis perde o direito à pensão? O que dizem os múltiplos ecos e linguajares da tradição?

A hipótese que ora se formula é de que a CHD não oferece ferramentas para esta função secundária de interpretação porque há um desacerto na leitura que Streck faz de Nietzsche. Parece não haver dúvida que fatos condicionam interpretações - nesse ponto está-se de acordo com a CHD. Se cinquenta pessoas olham para um barco, dificilmente alguma delas dirá que se trata de um avião. 
Essa lógica de interpretar determinando obviedades ${ }^{30}$, definida por certos limites histórico-semânticos, não é capaz de tornar, por si só, mais louvável a afirmação de que fatos são mais importantes que interpretações. Observe-se: ainda que não pairem dúvidas sobre o fato de que o barco seja mesmo um barco, muito frisson haverá entre a plateia de intérpretes sobre as propriedades desse barco: sua cor e sua velocidade, suas virtudes e suas falhas, sua capacidade e sua potência, sua altura e sua fundura, seus parafusos imensos e diminutos, sua curvatura mais ou menos angulada.

Intermediada pela linguagem e articulada por linguajares, a interpretação, capaz de dizer que aquele barco é $a-q-u-e-l-e$, e não outro, estará submetida crucialmente aos sistemas de orientação e significação de quem se dispõe a interpretar o infinito de detalhes do barco. Se os mil vieses com os quais podem ser interpretados o barco (que já ninguém ousa chamá-lo de avião) já podem confundir as interpretações mais dispostas, ao transportar-se o dilema da interpretação de fatos para o complexo universo jurídico, mais divergências, por certo, haverá.

\section{OS DISTANCIAMENTOS ENTRE NIETZSCHE E A CRÍTICA HERMENÊUTICA DO DIREITO}

É costume dizer-se que contra fatos não há argumentos. Ora, só contra fatos é que há argumentos. Os argumentos são, quase sempre, mais verdadeiros do que os fatos. A lógica é o nosso critério de verdade, e é nos argumentos, e não nos fatos, que pode haver lógica.

Fernando Pessoa31

No item anterior, sublinhou-se que, apesar de reconhecer a importância da hermenêutica filosófica em auxiliar a interpretação a dizer certas obviedades históricas, ela não fornece meios para definir, dentro do material que a tradição

30 Streck descreve diálogo com uma professora para fazer uma afirmação hermenêutica: "Em um seminário na Itália há uns 8 anos atrás, fui interrompido durante a exposição por uma professora de pendores relativistas, dizendo: "- Você diz que existem verdades e que uma interpretação deve poder ser avaliada como melhor do que outra e que podem existir respostas corretas em direito, que você chama 'adequadas a Constituição'. Muito bem. Mas, veja, professor Lenio: Nós dois olhamos para um, digamos, um barco. Cada um de nós vê um barco diferente do outro. Até, provavelmente bem diferentes. Então, como explica isso em relação ao que você prega? Respondi-lhe, candidamente: "- Bingo, caríssima professora. Perfeito. Começamos muito bem. Ambos vemos... um barco. Não é um avião". STRECK, Lenio. Fim da presunção da inocência, flagrantes on-line... e a Constituição? Consultor Jurídico. 09 set 2016. Disponível em: <http://www.conjur.com.br/2016-set-08/senso-incomum-fim-presuncaoinocencia-flagrantes-on-line-constituicao>. Acesso em: 17 de out 2017.

31 PESSOA, Fernando. Obras em prosa. Rio de Janeiro: Cia José Aguilar Editora, 1974, p. 582. 


\title{
delimita os contornos exatos de uma resposta correta, embaçando ao redor das lentes que pretendem interpretar todo o obtuso que circunda o óbvio.
}

\author{
Para Nietzsche ${ }^{32}$, na medida em que só existem interpretações, os fatos, em si,
} não existem. Tal posição é rechaçada pela CHD por meio de Streck, sob o argumento de que o julgador, ao preterir os fatos (e seus "DNA's"...) às suas interpretações, tem na possibilidade de interpretação uma justificação de seu arbítrio.

\section{O presente estudo avança para a seguinte divergência perspectiva: de um}

32 NIETZSCHE, Friedrich. Fragmentos Póstumos (1885-1887). São Paulo: Editora Forense Universitária, 2013. v. 7. p. 60. De se consignar a importante nota explicativa de CORBANEZI, E. R. Perspectivismo e relativismo em Nietzsche. 2013. 107 f. Dissertação (mestrado) - Faculdade de Filosofia, Letras e Ciências Humanas, Departamento de Filosofia, Universidade de São Paulo, São Paulo, 2013: "Para referir-se ao conceito de interpretação, Nietzsche emprega termos como Interpretation, Auslegung, Deutung e Ausdeutung. Nas notas acrescentadas às suas traduções da obra de Nietzsche para a língua francesa, Patrick Wotling considera que, mesmo sendo impossível fazer uma distinção absolutamente estrita entre esses termos, o uso que o filósofo faz deles indica sentidos diferentes, conforme o contexto em que aparecem. Recebendo conotação mais positiva, Auslegung tem com frequência o sentido de explicitação e glosa de um 'texto' ('texto' em seu sentido metafórico e abrangente, segundo o qual todo fenômeno e todo processo constituem um texto a ser decifrado), ao passo que Interpretation, Deutung e Ausdeutung carregam geralmente sentido pejorativo, expressando a crítica de Nietzsche em relação a desvios, falhas e falsificações - inconscientes ou desonestas - das leituras, traduções e interpretações (a respeito dessa diversidade de vocabulário e de sentidos, consultar algumas das notas de tradução sobre o termo 'interpretação', entre as quais as seguintes: 101, 104, 118, 132, 142, 145, 157, 195, 261 , 309, 485, 556, 578, presentes em Par-delà bien et mal, trad. de Patrick Wotling. Paris: Flammarion, 2000). Embora em determinados momentos Nietzsche confira sentido a esses termos tal como Wotling os distingue, o próprio tradutor assinala, como se mencionou, a impossibilidade de realizar uma distinção estrita dos sentidos mobilizados pelo filósofo. Com efeito, observa-se que em certas ocasiões Nietzsche emprega 1) os termos em acepções contrárias às delimitações de Wotling, 2) como intercambiáveis termos que, conforme as observações de Wotling, possuiriam diferentes sentidos, 3 ) o mesmo termo com sentidos opostos. Para exemplificar o primeiro caso, leia-se o seguinte fragmento póstumo: 'Contra o positivismo, que permanece no fenômeno 'há apenas fatos', eu diria: não, precisamente não há fatos, apenas interpretações [Interpretationen]. Não se pode constatar nenhum factum 'em si' [...]. 'Tudo é subjetivo', dizem vocês: mas isso já é interpretação [Auslegung], o 'sujeito' não é nada dado, mas sim algo inventado-a-mais, colocado-por-trás. - Por fim, é mesmo necessário pôr o intérprete (Interpreten) atrás da interpretação [Interpretation]? Isso já é invenção, hipótese. Enquanto em geral a palavra 'conhecimento' tiver sentido, o mundo será 'cognoscível': mas ele é diferentemente interpretável [deutbar], ele não tem nenhum sentido atrás de si, mas sim incontáveis sentidos[.] 'Perspectivismo' (Nachlass/FP 1886-1887, 7[60], KSA 12.315). Nesse fragmento póstumo, Auslegung se refere a uma interpretação criticada por Nietzsche, a que postula a realidade do sujeito. Em contrapartida, o filósofo emprega o adjetivo deutbar na ocasião em que utiliza a afirmação de que o mundo é interpretável (deutbar) em favor de seu perspectivismo. Aqui, Auslegung e deutbar não têm os sentidos indicados por Wotling. Em outras ocasiões, Nietzsche utiliza como intercambiáveis termos diferentes (Auslegung e interpretiren), que, conforme as observações de Wotling, teriam sentidos opostos. Tome-se como exemplo o fragmento póstumo em que Nietzsche afirma que 'a estimativa moral de valor é uma interpretação [Auslegung], um modo de interpretar [interpretieren]' (Nachlass/FP 1885-1886, 2[190], KSA 12.161). Por fim, ocorrem situações em que Nietzsche emprega o mesmo termo para caracterizar técnicas de interpretação opostas. No parágrafo 22 de Para além de bem e mal, por exemplo, embora utilize as expressões 'schlechte Interpretations-Künste' e 'Ausdeutung' para se referir à 'schlechten Philologie' da legalidade da natureza, Nietzsche também emprega o termo Interpretation para referir-se precisamente à arte de interpretação oposta ('entgegengesetzen Absicht und Interpretationskunst'), isto é, à sua própria arte de interpretação, assim como se refere a ele próprio como Interpret e à interpretação do mundo como vontade de potência como Interpretation (JGB/BM 22, KSA 5.37). Ou seja, o termo Interpretation é aplicado tanto para caracterizar a arte de interpretação criticada por Nietzsche quanto para reportar-se à própria interpretação de Nietzsche. Éric Blondel (1986, 139-140) também procura, mas de modo ligeiramente diferente, distinguir os sentidos que Nietzsche faz operar no uso de palavras diversas para se referir ao conceito de interpretação: "Portanto, há lugar para, por respeito ao texto, distinguir, se possível, a Deutung ou Auslegung (exegese, interpretação em sentido estrito) da Interpretation, comentário mais ou menos livre, glosa acrescentada infiel ao texto". 
lado a de Nietzsche, para quem a interpretação é uma condição incontornável, já que impossível o acesso ao fato em si; e, de outro, a de Streck, que impugna a premissa nietzschiana ${ }^{33}$ em defesa de um controle rígido das decisões judiciais e do combate dos voluntarismos dos juízes.

Note-se que, em sentido oposto ao de Gadamer, Nietzsche não percebe a atividade de interpretação condicionada à necessidade de dar-ouvidos-à-tradiçãa, mas como construção projetiva de sentido, afeito mais ao conceito de devir présocrático do que ao conceito platônico de verdade. Mesmo que se admita que o intérprete só cria compreensão a partir do material dado pela tradição, qualquer interpretação daí decorrente será sempre um resultado, ainda que justificável, contingente, eis que uma entre as múltiplas respostas oferecidas pela tradição.

E a contingencialidade é inevitavelmente exposta por intermédio de narrações, de linguajares. Parta-se ou não do material dado pela tradição, interpretar é fazer um determinado uso da linguagem, desde sempre, portanto, narração. Tais premissas, associadas ao verdadeiro dilema que representa o (impossível) controle da subjetividade, atestam que a variabilidade é uma espécie de natureza intrínseca da experiência interpretativa.

Depois de Nietzsche, não se pode defender propostas metodológicas com quaisquer tendências objetivistas, ainda que, para isso, discursivamente, seja necessário escamotear a objetividade. A partir da autodeclaração de que está a meio caminho entre o objetivismo e o subjetivismo, a CHD fixa controversa tese. A "cadeira posta entre o objetivismo e o subjetivismo" pende, a nosso sentir, muito mais ao objetivismo do que para a centralidade. Esse pé no objetivismo é assumido pela própria CHD ao afirmar: "há um grau de objetivismo necessário..."34. Observa-se que, primeiro, a CHD objetifica a própria tradição, na medida em que a alça como lugar reitor de onde se deve sempre (e não menos que sempre) partir o exame primeiro de qualquer atividade interpretativa. Segundo, porque objetifica a própria linguagem, na medida em que se apoia na crença de uma unicidade e de uma unissonicidade da linguagem.

33 Diz Streck: "A tese nietzschiana de que não existem fatos, só interpretações, parece-me sem sentido nessa quadra da história. Para mim, só há interpretações porque existem fatos. Na hermenêutica não há problema em trabalhar com a verdade." STRECK, Lenio. Hermenêutica e Jurisdição. p. 115. 
Mas por que ainda se resvala na metafísica clássica que chega, com propostas escamoteadas, até a hermenêutica filosófica de Gadamer e à CHD de Streck? Ao seguir-se a trilha nietzschiana, há de se criticar a vontade-de-verdade nos principais sistemas filosóficos e também jurídicos do Ocidente. É essa vontadede-verdade que constrói o que Nietzsche chamou de ideal ascético ${ }^{35}$. Nietzsche despreza as unidades metafísicas de sentido e faz do manuseio da linguagem a exteriorização do produto da consciência, sempre submetida a um contexto $x$ e a uma subjetividade y.

Derrida é quem, primeiramente, criticou a leitura heideggeriana de Nietzsche, uma vez que, para o filósofo francês, Heidegger não foi capaz de superar o racionalismo metafísico, já que manteve intacto o postulado de que todo processo interpretativo busca encontrar um sentido. Nietzsche, em contrapartida, não entendia a interpretação como a busca de um sentido que já estava dado e que deveria ser encontrado (mediante, por exemplo, o revolvimento da tradição...), mas como atividade relacionada à satisfação da vontade de poder/ potência. Assim, a afirmação da interpretação como atividade adstrita aos limites do intérprete inevitavelmente retirou todo caráter metafísico da hermenêutica proposta por Heidegger e, depois, também por Gadamer ${ }^{36}$.

Pode-se perceber a contrariedade de Nietzsche em relação ao caráter divino que Gadamer confere à tradição na seguinte passagem de A Gaia Ciência:
A. Estava eu doente? Estou agora são? Quem foi meu médico? Como pude esquecer tudo!

B. Agora sim, creio que está são: pois sadio é quem esquece.37

Considerando, com Nietzsche, o esquecimento como virtude, enfraquecese o uso soteriológico do conceito de tradição na decisão judicial, notadamente, a

35 NIETZSCHE, Friedrich. Genealogia da Moral - uma polêmica. São Paulo: Companhia das Letras, 1998. p. 140, "O ideal ascético dominou todas as filosofias pelo fato de que a verdade era postulada como Ser, como Deus, como instância suprema, pelo fato de que a verdade não devia de modo algum constituir um problema (...) esta vontade absoluta de verdade, não nos enganemos, é a fé no próprio ideal ascético, mesmo quando for apenas seu imperativo inconsciente; é a fé em um valor metafísico, em um valor em si da verdade que apenas esse ideal garante e consagra (ela subsiste e perece com ele)."

36 SÁENZ, Maria Carmen López. ¿Verdad o interpretaciones? Gadamer versus Nietzsche. Eukasia: Revista de Filosofia, Madrid,2014. p. 107.

37 NIETZSCHE, Friedrich. A Gaia Ciência. p. 19. 
partir de três críticas: (1) a impossibilidade de objetificar a tradição de determinado conceito ou fenômeno, bem como de objetificar a linguagem usada para narrar a perspectiva da tradição eleita pelo intérprete; (2) a impossibilidade de se suspender, ainda que temporariamente, os juízos chamados por Gadamer de inautênticos do intérprete. Afinal, uma pergunta: quem será o juiz dos juízes capaz de julgar essa (in)autenticidade?; (3) a impossibilidade de manter um fundamento único/ unívoco (a autenticidade por meio do diálogo com a tradição) capaz de dar um sentido correto à interpretação.

A negação do caráter subjetivo da interpretação absorvido pela CHD é clara em Gadamer38: "A compreensão deve ser pensada menos como uma ação da subjetividade e mais como um retroceder que penetra num acontecimento da tradição...". É assim que, a nosso ver, a hermenêutica filosófica resvala em um ideal ascético, a que chama de tradição, na medida em que tenta prestigiá-la, talvez para escapar do incômodo das arbitrariedades, lado negativo da subjetividade.

Na medida em que admite que é na profundeza da tradição que se pode encontrar a natureza intrínseca daquilo que se pretende interpretar via diálogo, a hermenêutica gadameriana e a CHD elegem a tradição e um pretenso "diálogo" com ela, seu Deus eleito, sua religião. O mundo das ideias e o mundo das aparências. Ou, o céu e o inferno, só que agora transformados, de novo platonicamente, em autenticidade e inautenticidade. Mostra-se ingênuo conceber que, com o exercício mental de retroceder "ao acontecimento da tradição" - ainda que não se saiba exatamente sobre qual das inúmeras perspectivas sobre a tradição se trate, seja possível conscientizar a história de determinado fenômeno, a fim de "descascar linguisticamente o fenômeno"39. O intérprete de Gadamer e o julgador da CHD não são capazes, nem teórica nem realisticamente, de escapar de sua própria subjetividade, ainda que prescientes de que seus (pré)juízos condicionam de modo fulcral seus exercícios hermenêuticos.

38 GADAMER, Hans-Georg. Verdade e Método I. p. 385.

39 "O método hermenêutico-fenomenológico adaptado pela CHD parece ter os elementos necessários para se chegar à compreensão dos fenômenos. Revolve-se o chão linguístico em que está (sempre) assentada uma determinada tradição; reconstrói-se-lhe a história institucional, fazendo com que o fenômeno se desvele, como em um palimpsesto [...] O revolvimento do chão linguístico implica desler as coisas. $\mathrm{E}$, ao desler, a coisa exsurge sob outra vestimenta fenomenológica [...]." Em STRECK, Lenio. Dicionário de Hermenêutica. p. 140. Consultar também STRECK, Lenio. Lições de Crítica Hermenêutica do Direito. Porto Alegre: Livraria do Advogado, 2015. 
Ao se conjecturar a importância dada por Gadamer e por Streck ao conceito de tradição, com a tendência iconoclasta da filosofia de Nietzsche, não seria exagero afirmar que toda a proposta hermenêutica que coloca o diálogo com a tradição como condição única de obtenção de um sentido legítimo é, seguindo a trilha de Nietzsche, doentia. Tentativas de transportar o arcabouço teórico da hermenêutica filosófica para o Direito buscam criar seitas teóricas que propugnam um messianismo sem Deus ou que fazem da tradição e da Constituição seus deuses.

Ao contrariar a lógica nietzschiana ${ }^{40}$, a CHD esquece-se de que é a narração, articulada por meio de uma interpretação, que trama os fios de sentido entre o fato passado e o que dele se compreenderá. Esse processo de reconstrução - algo que a hermenêutica filosófica chama de "revolver linguisticamente o fenômeno" 41 - não é feito sem que "a linguagem seja arrastada para fora de seus sulcos costumeiros" ${ }^{\prime \prime 2}$.

Assim, não se pode afirmar que o revolvimento linguístico do fenômeno, intermediado pela linguagem, materializado com narrações e seus linguajares, é capaz de pinçar, ilesa, a mensagem das mensagens ditada pela tradição, sem desviar, por pouco que seja, da subjetividade pessoal e cultural implicada no processo decisório.

Mesmo negando a objetividade, a CHD, ao associar-se ao estratagema tradição-via-linguagem de Gadamer, acaba cedendo à tentação da objetificação: não das coisas (metafísica clássica), nem do sujeito (metafísica moderna), mas da própria linguagem que deverá dizer a tradição (metafísica contemporânea).

Interpretar em Direito é dedicar-se à criação de um contato entre devires subjetivos e narrativas processuais e seus peculiares linguajares. A narração pertence à categoria do artifício, da arte de ficcionar, de criar histórias. A natureza

40 STRECK, Lenio. A crítica hermenêutica do direito e o pensamento de Lenio Streck. Entrevista concedida à Revista Espaço Jurídico - Journal of Law, Joaçaba, v. 17, n. 2, Joaçaba, maio/ago 2016. p. 387-410. "Sou antinitscheano. Quando ele diz que fatos não existem e que só existem interpretações, eu digo: só existem interpretações porque existem fatos".

41 Conforme entrevista de Lenio Streck, "revolvido o chão linguístico em que se aloja a tradição do fenômeno, reconstrói-se a sua história institucional. Ao final, já estaremos em frente a um outro fenômeno." STRECK, Lenio. A crítica hermenêutica do direito e o pensamento de Lenio Streck. p. 387-410.

42 DELEUZE, Gilles; GUATTARI, Felix. Mil Platôs: Capitalismo e Esquizofrenia. 2. ed. Tradução de Aurélio Guerra Neto e Célia Pinto Costa. São Paulo: Ed. 34, 1995. 
das narrativas processuais, dadas a criar e assumir por (mais) verdadeiros fatos a partir de linguajares - sempre interessados -, autodeclara a impossibilidade de teoricamente falar-se em respostas corretas, em respostas mais adequadas que todas as outras possíveis.

A narrativa precede à tradição nos mesmos moldes que o existencial se antecipa ao essencial ${ }^{43}$. A partir dessa paisagem teórica, a tentativa de fazer com que uma linha reta una o fato-em-si a uma narrativa é delírio. Diz Nietzsche: "não há linha reta, nem nas coisas nem na linguagem"44. E acrescenta-se: não há linha reta nem na tradição, nem na linguagem.

"Matar" a tradição, na mesma linha de fuzilamento em que caíram Deus, o Estado, a Ciência, a Verdade e outros ídolos, coloca Nietzsche como o anunciante de uma aurora no campo hermenêutico: o das interpretações movediças. Nietzsche destrona ídolos na medida em que problematiza os fundamentos metafísicos de sentido das idealizações, das objetificações. No prelúdio de A Gaia Ciência ${ }^{45}$, Nietzsche escreve uma intrigante quadra poética titulada Prudência mundana:

Não fique no rés-do-chão.

Não suba alto demais!

O mundo parece belo à meia altura.

Ainda que, à primeira vista, a quadra possa sugerir a ideia da velha prudência aristotélica, observa-se que Nietzsche antecipa a noção de perspectivismo, na medida em que coloca como virtude a capacidade de negar a intenção totalizante e panorâmica que só o cume de uma montanha pode propiciar. Ao sugerir que a beleza está associada à parcialidade da vista daquele que fica "à meia altura", Nietzsche elogia o fato de que a verdade é feita de olhares necessariamente parciais. "O mundo tornou-se novamente 'infinito' para nós na medida em que não podemos rejeitar a possibilidade de que ele encerre infinitas interpretações" 46 . 43 Sentido emprestado de SARTRE, Jean-Paul. El existencialismo es un humanismo. 1. ed. Barcelona: Edhasa, 2009.

44 DELEUZE, Gilles. Crítica e Clínica. 2. ed. Tradução de Peter Pál Pelbart. São Paulo: Editora 34, 2011. p. 12.

45 NIETZCHE, Friedrich. A Gaia Ciência. p. 19.

46 NIETZCHE, Friedrich. A Gaia Ciência. p. 278. 
Só existem interpretações porque a apreensão da totalidade dos fatos e dos fenômenos é negada. As narrativas que se produzem dentro de um processo judicial nunca comunicam um fato, transmitem apenas o que se ouviu sobre eles. Associam-se com as intenções estratégicas de quem narra e se concluem com uma narrativa inevitavelmente contaminada. Feita de discursos sempre indiretos, as narrativas processuais, inclusive as das decisões, dão conta de confirmar a sentença nietzschiana que conduz essa reflexão.

Deleuze $^{47}$ afirma que há uma impossibilidade fundamental de conceber a enunciação, seja falada ou escrita, pois "a linguagem é um mapa, não um decalque". A construção de narrativas pode ser comparada à técnica utilizada pelo movimento dadaísta ${ }^{48}$. Toda narrativa é uma colagem de operadores conceituais. Sendo assim, é possível manipular, retirar, colar e modificar as narrativas. Narrativas são inter-relações de conceitos científicos, poéticos, artísticos, literários e, claro, também jurídicos. Quem narra, inventa. A narrativa exerce a função de descrever o que a nossa subjetividade interpreta. Não busca uma identidade, mas afirma uma diferença, um ponto de vista, uma perspectiva. Interpretar é colocar os conceitos a serviço de um projeto narrativo.

Daí porque Calvo corroborará a frase de Nietzsche, ao afirmar que os dilemas que exsurgem da ausência de critério cognitivo unívoco de verdade ou falsidade não pedem a recuperação do que chama de "fundo mineral" da verdade. Para o autor, a concepção de verdade é muito mais arenosa e movediça do que rochosa. Isso, contudo, não implica um pessimismo epistemológico ou mesmo um relativismo radical - como brada a Crítica Hermenêutica do Direito. Tratase de considerar que "não existe verdade que possa ser descoberta via diálogo com a tradição" e, ainda, que a vontade-de-verdade tem um duplo sentido: 1) nos processos judiciais, as verdades são narrativamente inventadas; 2) não se perde a verdade pelo fato de que haja mais de uma perspectiva narrativa: a verdade da

47 DELEUZE, Gilles; GUATTARI, Felix. Mil Platôs. p. 14-15. "Não acreditamos, a esse respeito, que as narrativas consistam em comunicar o que se viu, mas em transmitir o que se ouviu, o que o outro disse. Ouvir dizer. Nem mesmo basta evocar uma visão deformante vinda da paixão. A primeira linguagem, ou, antes, a primeira determinação que preenche a linguagem, não é o tropo ou a metáfora, é o discurso indireto."

48 MACHADO, Roberto. Deleuze, a arte e a filosofia. Rio de Janeiro. Jorge Zahar Ed., 2009. p. 29-31. O movimento Dadá (Dada) ou Dadaísmo foi um movimento artístico iniciado na Suíça em 1916. Formado por escritores, poetas e artistas plásticos, o grupo tem em Tristan Tzara, Hugo Ball e Hans Arp seus precursores. Embora a palavra dada em francês signifique "cavalo de madeira", sua utilização marca o non-sense ou falta de sentido que pode ter a linguagem (como na fala de um bebê). GOMBRICH, Ernest Hans Josef. A História da Arte. 16. ed. Tradução de Álvaro Cabral. Rio de Janeiro: LTC, 1999. 
verdade judicial fala por si mesmo, em outra história contada. Afinal, no Direito, há sempre, no mínimo, duas histórias da verdade a serem contadas $^{49}$.

Para desconstruir a divindade que Gadamer e Streck conferem à tradição, Hobsbawm ${ }^{50}$ pode ser auxiliar, na medida em que demonstra que as tradições podem ser inventadas. Como tradição inventada, segundo o autor, "entende-se o conjunto de práticas, normalmente reguladas por regras tácitas ou abertamente aceitas [...] que visam inculcar certos valores e normas através da repetição, o que implica em uma continua relação com o passado". Para a hermenêutica filosófica, tem-se que interpretações são autênticas na medida em que permitem que os (pré)conceitos inautênticos do intérprete o impeçam de escutar aquilo que the diz a tradição. Todavia, a vingar a tese de Hobsbawm, porque se constata que tradições podem ser inventadas, inclusive no que se refere a práticas institucionais na política e na jurisdição, não se pode mais levar a cabo as determinações gadamerianas. Mesmo porque a função das tradições inventadas "é dar a qualquer mudança desejada a sanção do precedente" ${ }^{\prime \prime}$, a se legitimar sempre a partir da continuidade do passado.

Ainda, é preciso atentar para o alerta feito por Gadamer ${ }^{52}$, para que não se corra o risco de deturpar o significado de tradição presente no projeto hermenêutico transportado para a CHD:

É evidente que a expressão que utilizo, às vezes, dizendo que importa aderir à tradição, favorece a mal-entendidos. Não significa uma preferência pelo tradicional, ao qual deveríamos nos submeter cegamente. A expressão 'adesão à tradição' significa, antes, que a tradição não se esgota no que sabemos de nossa própria tradição e da qual temos consciência, de tal modo que pudéssemos suspendê-la mediante uma consciência histórica adequada. A mudança do vigente é uma forma de adesão à tradição não menos que a defesa do vigente. A tradição se dá propriamente numa constante mudança. A 'adesão' a ela impõe-se como formulação de uma experiência, em virtude da qual nossos planos e desejos sempre se adiantam à realidade, como se não tivessem ligação com essa. O que importa, então, é fazer a

49 CALVO GONZÁLEZ, José. La verdad de la verdad judicial. Construcción y regimen narrativo. Revista Internazionale di Filosofia del Diritto, Milano, Giuffrè Editore, IV Serie - LXXVI - Fasc. 1. 1999. p. 53-54.

50 HOBSBAWM, Eric J. A invenção das tradições. 10. ed. Tradução de Celina Cardim Cavalcante. São Paulo: Paz e Terra, 2015. p. 8.

51 HOBSBAWN, Eric J. A invenção das tradições. p. 9.

52 GADAMER, Hans-Georg. Verdade e método II: complementos e índice. 4. ed. Tradução de

Enio Paulo Giachini e revisão de Marcia Sá Cavalcante. Petrópolis, RJ: Vozes, 2009. p. 312. 
intermediação entre as antecipações do desejável e as possibilidades do factível, entre o mero desejo e o querer real, isto é, conformar as antecipações no material da realidade. É claro que isso não se dá sem distinções críticas. Eu diria até que a única crítica real é a que 'decide' nessa relação prática.

Ainda que o diálogo com a tradição não implique uma "obediência cega" a ela - alerta feito pelo próprio Gadamer ${ }^{53}$-, observa-se que, na medida em que se coloca a tradição como "pano de fundo"54 interpretativo, ou como fundamento único capaz de emitir premissas interpretativas com as quais, do presente, se pretende dialogar, afasta-se a ideia de verdade como construção e aproxima-se, ainda mais, da ideia de verdade como descoberta. Repete-se, assim, a mesma operação platônica e objetivista de busca da verdade. Ainda que o diálogo entre passado e presente se pretenda crítico, serão os usos da linguagem, suas colocações, os momentos de enunciação escrita ou falada que fornecerão, enfim, os meios para que a verdade seja não mais desvendada ou descoberta, mas construída.

A sugestão de uma pretensa estabilidade da tradição possibilita uma crítica conceitual a ela a partir de um olhar nietzschiano. Como processo necessariamente genealógico, o diálogo com a tradição é atravessado por palavras com sentidos movediços, por desejos em descaminho, por ideias sem lógica aparente, por fatos históricos narrados por perspectivas vitoriosas ou frustradas. Se não há louco capaz de negar o holocausto, há que se admitir que sua compreensão encerra perspectivas múltiplas. O mundo de coisas ditas do e sobre o passado pode ter "conhecido invasões, lutas, rapinas, disfarces, astúcias"55, bem como pode ter apagado o não dito, deixando, com aparência a-histórica, aquilo que compôs a ocorrência de fatos cruciais como sentimentos, afetos, instintos, brutalidades, interesses e ideologias prevalecentes. E disso também são feitos juízes e suas decisões, ainda fosse melhor não ser assim.

53 GADAMER, Hans-Georg. Verdade e Método I. p. 270.

54 Gadamer considera a tradição como sendo, assim como o preconceito, parte de um plano de fundo para o nosso engajamento no mundo. Nunca pode se tornar um objeto de investigação, pois se está sempre dentro dela e nunca se pode encontrar um ponto fora dela para testar sua validade. Para se poder juntar a tradição e a vida histórica (historicidade), e para se poder mostrar como se é inescapavelmente histórico e parte da tradição, porém não preso e seduzido por ela, deve-se voltar nossa atenção para um termo-chave na léxica de Gadamer, o "horizonte" e aquilo que ele chama de "fusão dos horizontes". LAWN, Chris. Compreender Gadamer. Tradução Hélio Magri Filho. Petropólis, RJ: Editora Vozes, 2007. p. 91.

FOUCAULT, Michel. Microfísica do poder. p. 15. 
Diante do exposto, com Sartre e Posner, é possível concluir que é necessário fazer algo daquilo que tem sido trabalhado como (teoria da) decisão judicial no Brasil. Assim, considerando que o comportamento e o modo de decidir dos juízes são motivados por desejos - admita-se ou não -, inevitável supor que as zonas de indeterminação de certas decisões forçam a conclusão de que os métodos exclusivamente normativistas oferecem possibilidades tão boas quanto ineficientes. Essa insuficiência é resultado, diz Posner ${ }^{56}$, de uma doença acadêmica: a carência de realismo em relação aos juízes.

A Crítica Hermenêutica do Direito funda-se a partir de apenas uma das tantas características de Hermes Trismegisto. Esquece inúmeros aspectos desta complexa figura mitológica que é Hermes, deus mensageiro, mas também deus das ciências ocultas. Desse modo, a concepção de tradição usada pela $\mathrm{CHD}$ não atende à sua própria tradição mitológica. A coisa que fala a tradição sobre o conceito de hermenêutica, fala de um deus complexo, embusteiro, astuto, traidor de verdades, persuasivo. Ao dissociar-se do caráter contingente ligado a isso - que no hermetismo denominam-se "ciências ocultas" -, a CHD inflaciona o caráter interpretativo de Hermes e, por isso, despercebe as sombras inconscientes na decisão judicial, despercebe o caráter ambíguo, perspectivo, inventivo e estratégico das mensagens (textos). Será a CHD inautêntica em relação à sua própria tradição mitológica?

A abertura aterradora dessa questão no âmbito da filosofia da decisão judicial não afasta a virtude da CHD, útil ferramenta para juízes capazes de compreendê-la para dela fazer bom e democrático uso do Direito. Os apontamentos alinhados na presente pesquisa buscaram contribuir para o aprimoramento da $\mathrm{CHD}$, notadamente em relação à abertura quanto aos aspectos não normativos imbricados na decisão judicial.

Essa perspectiva pretende demonstrar que, notadamente no Brasil, país de tradição multi-identitária, as interpretações judiciais são muito mais próximas ao uso de linguajares do que de uma Linguagem, com os ares maiúsculos com o qual a CHD a eleva. Enquanto a linguagem pretende-se oficial, capilar, abrangente e, por isso, objetificável, os linguajares estão mais próximos dos sotaques, da adaptação em nome da compreensão, da dimensão dos detalhes, das particularidades microfísicas, dos sulcos não evidentes dos textos, do não dito. A empiria é fatal: inúmeras decisões judiciais no Brasil não são materializadas por 
uma linguagem, mas por linguajares, por sotaques. Paradoxalmente, isso obedece à tradição brasileira: jeitosa, temperamental, manhosa, malandra ${ }^{57}$. E isso - feliz ou infelizmente - não se coaduna com uma cobrança de cumprimento pleno da Constituição, nem com a correlata crença de que pode haver uma "igualdade" metodológica entre os milhares de juízes no Brasil, nem mesmo da própria metodologia, para que, claramente, proponha dispositivos capazes de oferecer respostas (sempre e não menos que sempre) corretas. Posner ${ }^{58}$ é certeiro: mesmo os teóricos que defendem um juiz capaz de seguir, mecanicamente, determinadas cartilhas de cumprimento da normatividade, sabem que a maioria dos juízes não faz isso na maioria de suas decisões.

Como sói acontecer com a maior parte das propostas teóricas sobre a teoria da decisão, a CHD também protagoniza a figura do julgador. $\mathrm{E}$, na medida em que centraliza toda a teoria no julgador, esvazia os espaços dos outros que participam do desfecho de um processo. Com Calvo, sugeriu-se a descentralização do poder do julgador, na medida em que se ressaltam as capacidades persuasivas das narrativas fáticas de quem litiga. Teorias da decisão que desprezam a interferência das partes nos julgamentos sofrem da mesma doença já destacada por Posner durante essa reflexão: falta de realismo. Ao se debruçar mais no sentido do que nas promessas de sentido, as teorias da decisão usam um conhecido dispositivo da ciência moderna: o recorte. Ao mesmo tempo em que a virtude dessa postura é a potência-de-profundidade, o recorte afasta as partes antes integradas, que inevitavelmente interferem no conteúdo daquilo que se recortou. A nova ciência da decisão judicial se esforça para refletir a partir da reconstrução dessas partes cortadas.

O uso do conceito de tradição da Hermenêutica Filosófica é inconsistente na $\mathrm{CHD}$, porque mesmo as respostas mais autoevidentes em relação ao

57 Existem fartas e ricas pesquisas sobre as origens da malandragem, da corrupção e do jeitinho brasileiro. No entanto, nossa lusitanidade é que legitima historicamente nossa chaga. Conta-se que Lisboa foi fundada por Ulisses, que ali descansou depois da longa batalha de Troia. Daí o nome da cidade, Ulissabon que, do grego, significa a cidade de Ulisses. "Aquilo que Aquiles não conseguiu durante dez longos anos pela força, Ulisses realizou com a esperteza a partir do estratagema do cavalo de Troia." Nossa identidade é marcada, desde a origem lusitana, por truques, trapaças, arranjos, corrupções, malandragens. Não é sem razão que Pedro Malasartes, Macunaíma, Zé Pelintra e Malandro Carioca são figuras simbólicas do nosso folclore. Apesar de nossa corrupção ser especializada em política, já os primeiros juízes brasileiros, todos bacharéis portugueses cedidos pela Coroa, ficaram marcados pelas associações interessadas que realizaram com as filhas dos senhores de engenho e das famílias tradicionais donas dos grandes latifúndios. Para esses, o parentesco com alguém ligado aos Tribunais, garantia de segurança e benefícios. Para aqueles, significava unir o poder institucional com o poder inerente à condição de detentor da propriedade privada. Anotação embasada nas obras: BOECHAT, Walter (Org.). A Alma Brasileira: luzes e sombras. Petrópolis, RJ: Vozes, 2014 e SCHWARTZ, Stuart B. Burocracia e Sociedade no Brasil Colonial. São Paulo: Cia das Letras, 2010.

58 POSNER, Richard. ¿Cómo deciden los jueces?. p. 16, "Nossos juízes têm e exercem discricionariedade. Especialmente se são desembargadores e ministros [...] São legisladores ocasionais. Para entender a atividade que desempenham é necessário entender a natureza de suas motivações, suas faculdades, seus mecanismos de seleção, as normas de sua profissão e sua psicologia." 
texto constitucional - como a que refere que condenados só possam ser presos após trânsito em julgado - deixam de ponderar aspectos da complexidade jurídica, cultural, social e mesmo econômica. A tarefa da redescrição ao longo da história, conforme propugna Richard Rorty ${ }^{59}$, é um modo-de-ser da própria história. Assim, a noção de legitimação pela tradição, ainda que se saiba que não se trata de mera repetição da história, como se anotou, é impossível, vez que tal legitimação não pode ser feita imune a atravessamentos subjetivos, culturais e inconscientes.

A hermenêutica filosófica aplicada ao Direito pela CHD satura-se diante de uma inflação de sua vontade-de-verdade. A epígrafe de sua cartilha diz: "À verdade. E para ela, à tradição". Mas há que se questionar: qual tradição? Condena-se a própria dinâmica da vida quando se imagina que milhares de juízes podem chegar a uma mesma consciência dos efeitos da história de fenômenos, conceitos ou institutos entrecruzados em um processo. Ao mesmo tempo em que critica a postura narcísica e endeusada de uma parcela considerável da magistratura brasileira ${ }^{60}$, também cobra desses mesmos juízes uma postura divina, para que eles, respeitando a Sagrada Constituição, encontrem - sempre e não menos que sempre - a melhor e mais adequada resposta em cada caso.

A CHD não enfrenta o problema da interpretação dos princípios como canais de comunicação com a tradição. Esse dilema está no cerne dos chamados hard cases. É neles que se encontram os dilemas em torno das questões que a normatividade não dá conta. É por essa razão que hoje, passados mais de cem anos da revolução freudiana do inconsciente, teorias demasiado conscientes, tendem a falar apenas da metade do assunto. A premissa de que a apreensão da realidade escapa da possibilidade de compreensão é, ao mesmo tempo, alívio e terrificação. A hipótese do inconsciente, como um grande sistema de alargamento da causalidade, pede uma leitura dos fenômenos a partir da sua afirmação teórica e de sua confirmação clínica. A inegável contribuição da ciência psicológica força que as leituras de fenômenos importantes da sociedade civil, especialmente aqueles intensamente influenciados pela subjetividade humana, como a resolução jurídica de conflitos, os processos pedagógicos, as práticas religiosas ou a gestão de pessoas, sejam revistos, reanalisados, redescritos e rearranjados.

Outro esquecimento das teorias sobre o viés meramente consciente da decisão é o da condição pessoal dos juízes. Ainda que se possa criticar as posturas tomadas nas decisões, nos votos e nas determinações, 0

59 RORTY, Richard. Contingência, ironia e solidariedade. Lisboa Editorial Presença, 1992.

Ver, nesse sentido, a obra STRECK, Lenio. Juiz não é Deus. 1. ed. Curitiba: Ed. Juruá, 2016. 
caminho aponta para a compreensão, a absorção e o entendimento das entranhas, daquilo que Warat chamava de reservas selvagens, em evidente alusão ao inconsciente teorizado por Freud ${ }^{61}$. Aliás, sobre o mestre que foi Warat para a Escola Crítica de Direito no Brasil, uma das melhores teorias sobre a decisão jurídica já elaboradas, como de fato é a Crítica Hermenêutica do Direito, encerra-se no conceito de senso comum teórico dos juristas. Observa-se que, no recente Dicionário de Hermenêutica, obra que reúne os quarenta cânones da CHD, o único verbete que lembra a perspectiva waratiana é "senso comum teórico dos juristas". Ainda que Warat não tenha encerrado suas reflexões e sua obra alicerçadas sobre a decisão judicial, ocupou-se, em sua fase madura, com o tema da resolução de conflitos, gênero do qual a decisão judicial é espécie.

Interpretações autênticas sobre aspectos em conflito em uma decisão podem ser repelentes entre si. Ainda que Gadamer tenha ressignificado o conceito de autoridade62, no sentido de mostrar que não se trata de um expediente de sujeição, mas de reconhecimento, há que se complementar sua posição para afirmar que reconhecer, pelo menos no meio jurídico, é poder sujeitar. A experiência do mundo não é absoluta. Nem na linguagem, nem no objeto, nem na subjetividade. Portanto, ainda que se admita que a tradição é uma orientação, não há uma determinação histórica precisa nem dos fenômenos nem da linguagem que os narrará.

Mesmo apropriando-se de Dworkin e até sugerindo que a teoria dele tenha sido iluminada por Gadamer63, a CHD não justifica as diferenças de uso da historicidade como legitimador decisional entre a civil law brasileira e a common law norte-americana. Assim como a CHD não responde a uma relevante questão: quanto da atenção à tradição não torna as decisões jurídicas excessivamente conservadoras?

Uma pergunta final: como é possível oferecer as condições subjetivas, intelectuais, sensíveis e psíquicas para que os julgadores ajam com responsabilidade política? Quais são, enfim, as condições de possibilidade para que se aja com responsabilidade política?

61 Consultar WARAT, Luis Alberto, Epistemologia e Ensino do Direito. O Sonho Acabou. Florianópolis. Ed. Fundação Boiteux. 2004; A Digna Voz da Majestade. Florianópolis: Fundação Boiteux, 2007;

Surfando na Pororoca. Florianópolis: Fundação Boiteux, 2005; Territórios Desconhecidos: a procura surrealista pelos lugares do abandono dos sentidos e da reconstrução da subjetividade. 1. ed. Florianópolis: Fundação Boiteux, 2004.

62 A noção de autoridade como sujeição é incorreta porque o fundamento de autoridade de uma pessoa não é oriundo de uma submissão ou de abdicação da razão, ao contrário, o fundamento último da autoridade é proveniente de um ato de reconhecimento e de conhecimento. Ou seja, reconhece-se que o outro está em um patamar de conhecimento acima de nós e, em decorrência disso, tem prevalência sobre o nosso juízo. Desse modo, a autoridade não é imposta, mas conquistada. GADAMER, Hans-Georg. Verdade e Método I. p. 370-371. 


\section{REFERÊNCIAS DAS FONTES CITADAS}

BOECHAT, Walter (Org.). A Alma Brasileira: luzes e sombras. Petrópolis, RJ: Vozes, 2014.

BRENDÃO, Junito de Souza. Mitologia grega. 18. ed. Petrópolis, RJ: Vozes, 2009. v. I.

CALVO GONZÁLEZ, José. Derecho y Narración: materiales para una teoría crítica narrativista del Derecho. 1. ed. Editorial Ariel: Barcelona, 1996.

. La verdad de la verdad judicial. Construcción y regimen narrativo. Revista Internazionale di Filosofia del Diritto, Milano, Giuffrè Editore, IV Serie - LXXVI - Fasc. 1, 1999.

A controvérsia fática: contribuição ao estudo da quaestio facti a partir de um enfoque narrativista do Direito. In: TRINDADE, André Karam; GUBERT, Roberta; COPETTI NETO, Alfredo (Orgs.). Direito e Literatura: discurso, imaginário e normatividade. Porto Alegre: Núria Fabris Ed., 2010.

O Direito Curvo. Tradução de André Karam Trindade. Porto Alegre: Livraria do Advogado Editora, 2013.

CARVALHO, Luis Gustavo G. C., Estado de Direito e decisão jurídica: as dimensões não-jurídicas do ato de julgar. In: PRADO, Geraldo; MARTINS, Rui Cunha; CARVALHO, Luis G. G. Castanho de (Orgs.). Decisão Judicial: a cultura jurídica brasileira na transição para a democracia. Madri/ Barcelona/Buenos Aires/São Paulo: Marcial Pons, 2012.

CORBANEZI, E. R. Perspectivismo e relativismo em Nietzsche. 2013. 107 f. Dissertação (mestrado) - Faculdade de Filosofia, Letras e Ciências Humanas, Departamento de Filosofia, Universidade de São Paulo, São Paulo, 2013.

DELEUZE, Gilles. Mil Platôs: capitalismo e esquizofrenia. 2. ed. Tradução de Ana Lúcia de Oliveira. São Paulo: Ed. 34, 1995.

. Crítica e Clínica. 2. ed. Tradução de Peter Pál Pelbart. São Paulo: Editora 34, 2011.

DIVAN, Gabriel. Decisão Judicial nos crimes sexuais: o julgador e o réu interior. Porto Alegre: Livraria do Advogado, 2010.

DWORKIN, Ronald. O império do Direito. 2. ed. Tradução de Jefferson Luiz Camargo. São Paulo: Martins Fontes, 2007.

Uma questão de princípio. 2. ed. Tradução de Jefferson Luiz Camargo. São Paulo: Martins Fontes, 2005.

ELIADE, Mircea. História das crenças e das ideias religiosa. Rio de Janeiro: Ed. Zahar, 2011. V. II. 
Novos Estudos Jurídicos

FOUCAULT, Michel. Microfísica do poder. 24. ed. Tradução de Roberto Machado. Rio de Janeiro: Edições Graal, 1979.

GADAMER, Hans-Georg. Verdade e Método I. 7. ed. Tradução de Flávio Paulo Meurer Petrópolis, RJ: Editora Vozes, 2005.

Verdade e método II: complementos e índice. 4. ed. Tradução de Enio Paulo Giachini e revisão de Marcia Sá Cavalcante. Petrópolis, RJ: Vozes, 2009.

Hermenêutica em retrospectiva: a virada hermenêutica. Tradução de Marco Antônio Casanova. Petrópolis, RJ: Vozes, 2007. v. II.

Hermenêutica em retrospectiva: a posição da filosofia na sociedade. Tradução de Marco Antônio Casanova. Petrópolis, RJ: Vozes, 2007. v. IV.

GOLDBERG, Jacob Pinheiro. Psicologia e reflexões do inconsciente. São Paulo: Jacob Pinheiro Goldberg Editora, 1978.

GOMBRICH, Ernest Hans Josef. A História da Arte. 16. ed. Tradução de Álvaro Cabral. Rio de Janeiro: LTC, 1999.

GULOTTA, Guglielmo. Dinâmica psicossocial da decisão judicial. Revista do Ministério Público do Rio Grande do Sul, Porto Alegre, Nova Fase, V. 1, n. 22, 1989.

HOBSBAWM, Eric J. A invenção das tradições. 10. ed. Tradução de Celina Cardim Cavalcante. São Paulo: Paz e Terra, 2015.

HOMERO. Hino Homérico a Hermes. Tradução e comentários de Ordep Serra. São Paulo: Odysseus Editora, 2006.

JACKSON, Bernard. Law, Fact and Narrative Coherence. Liverpool: Deborah Charles Pub, 1998.

Narrative Models in Legal Proof. In: Narrative and the Legal Discourse: A reader in Storytelling and the Law. Liverpool: Deborah Charles Pub, 1991.

JUNG, C. G. Interpretação psicológica do Dogma da Trindade. 8. ed. Tradução de Márcia de Sá Cavalcante. Petrópolis, RJ: Vozes, 2011.

LAWN, Chris. Compreender Gadamer. Tradução Hélio Magri Filho. Petrópolis, RJ: Editora Vozes, 2007.

MACHADO, Roberto. Deleuze, a arte e a filosofia. Rio de Janeiro. Jorge Zahar Ed., 2009.

NIETZSCHE, Friedrich. Genealogia da Moral - uma polêmica. Tradução de Paulo César de Souza. São Paulo: Companhia das Letras, 1998. 
2001.

A Gaia Ciência. Tradução de Paulo César de Souza. São Paulo: Companhia das Letras, . Fragmentos Póstumos (1885-1887). São Paulo: Editora Forense Universitária, 2013. v. 7.

PHILLIPE, Jeanine Nicolazi. A lei: uma abordagem a partir da leitura cruzada entre direito e psicanálise. Belo Horizonte: Del Rey, 2001.

POSNER, Richard. Cómo deciden los jueces. Marcial Pons: Buenos Aires, Barcelona, Madrid, 2011.

PRADO, Lidia Reis de Almeida. O juiz e a emoção. 2. ed. Campinas: Ed. Milennium, 2008.

RORTY, Richard. Contingência, ironia e solidariedade. Lisboa: Editorial Presença, 1992.

SÁENZ, Maria Carmen López. ¿Verdad o interpretaciones? Gadamer versus Nietzsche. Eukasia: Revista de Filosofia, Madrid, 2014.

SARTRE, Jean-Paul. El existencialismo es un humanismo. 1. ed. Barcelona: Edhasa, 2009.

SCHWARTZ, Stuart B. Burocracia e Sociedade no Brasil Colonial. São Paulo: Cia das Letras, 2010.

STRECK, Lenio. Hermenêutica Jurídica. In: BARRETO, Vicente de Paulo. Dicionário de Filosofia do Direito. Ed. Unisinos/Renovar: São Leopoldo/Rio de Janeiro, 2006.

. Lições de Crítica Hermenêutica do Direito. Porto Alegre: Livraria do Advogado, 2015.

. A crítica hermenêutica do direito e o pensamento de Lenio Streck. Entrevista concedida à Revista Espaço Jurídico - Journal of Law, Joaçaba, v. 17, n. 2, maio/ago 2016.

. Juiz não é Deus. 1. ed. Curitiba: Ed. Juruá, 2016.

Fim da presunção da inocência, flagrantes online... e a Constituição? Consultor Jurídico, São Paulo, 09 set 2016. Disponível em: <http://www.conjur.com.br/2016-set-08/ senso-incomum-fim-presuncao-inocencia-flagrantes- on-line-constituicao >. Acesso em: 17 de out 2016.

Dicionário de Hermenêutica: Quarenta temas fundamentais da Teoria do Direito à luz da Crítica Hermenêutica do Direito. Belo Horizonte: Casa do Direito, 2017.

Hermenêutica e Jurisdição: Diálogos com Lenio Streck. Porto Alegre: Livraria do Advogado, 2017.

Sobre como o direito nos funda e a moral nos afunda. Consultor Jurídico, São Paulo, 07 set 2017. Disponível em: <http://www.conjur.com.br/2017-set-07/senso-incomumejaculador-direito-funda-moral-afunda>. Acesso em: 17 out 2017. 
TARUFFO, Michele. Precedente e Jurisprudência. Revista de Processo, São Paulo, RT, v. 199, 2011.

La prueba de los hechos. 4. ed. Traducción de Jordi Ferrer Beltrán. Madrid: Editorial Trotta, 2011.

WARAT, Luis Alberto. Epistemologia e Ensino do Direito: O Sonho Acabou. Florianópolis: Fundação Boiteux, 2004.

Territórios Desconhecidos: a procura surrealista pelos lugares do abandono dos sentidos e da reconstrução da subjetividade. 1. ed. Florianópolis: Fundação Boiteux, 2004.

. Surfando na Pororoca. Florianópolis: Fundação Boiteux, 2005.

. A Digna Voz da Majestade. Florianópolis: Fundação Boiteux, 2007. 